\section{Flower and Seed Production of Norway Maple Cultivars}

\author{
Janine R. Conklin ${ }^{1,3}$ and James C. Sellmer ${ }^{2}$
}

ADDITIONAL INDEX wORDs. Acer platanoides, ornamentals, invasive, landscape

Summary. Mature specimens of the norway maple (Acer platanoides) and cultivars Columnare, Crimson King, Emerald Queen, Faasen's Black, Globosum, and Rubrum were evaluated over a 3-year period to determine flower and seed production and to understand their invasive potential using seed yields. Flower and seed yield data were collected each year and were used to estimate whether differences existed among cultivars and if variation in these traits occurred from year to year. For this study, it was observed that norway maple cultivars differed in annual flower and seed yield and that production varied from year to year. 'Columnare', 'Emerald Queen', and the species produced many seeds, which suggest that these plants may be problematic in landscapes that adjoin natural areas. In contrast, 'Crimson King', 'Globosum', 'Faasen's Black', and 'Rubrum' were relatively low in seed yield, which make them suitable alternatives for landscape use where invasiveness is a concern to surrounding communities.

I nvasive species have been listed as the second highest threat to biodiversity in the United States surpassed only by habitat destruction (Bir, 2000; Morin, 1999; U.S. Department of the Interior, 1999; Wilcove et al., 1998). The projected economic losses due to invasive species are more than $\$ 138$ billion each year in the United States. About 5000 invasive plant species exist in the Unites States (Pimentel et al., 1999) which have invaded and disturbed habitats, altered ecosystems, and threatened endangered species (D'Antonio and Vitousek, 1992).

One way that invasive plants displace natives and reduce biodiversity of forest ecosystems is by producing many seeds that are capable of germination (Lehrer and Brand, 2003). Heavy flower production is required on the plant to yield high seed quantities (Augspurger, 1983). It is generally understood that the larger the mature plant, the higher the yield

\footnotetext{
This paper is submitted in partial fulfillment of the requirements for the $\mathrm{PhD}$ of the senior author.

Special thanks to the Holden Arboretum along with the Dawes Arboretum for the use of their plant collections, to the Pennsylvania Landscape and Nursery Association for supporting this work, and to Rich Marini and Jay Holcomb for internally reviewing this paper.

Department of Horticulture, Pennsylvania State University, 310 Tyson Building, University Park, PA 16802 .

${ }^{1}$ Graduate Assistant.

${ }^{2}$ Associate Professor.

${ }^{3}$ Corresponding author. E-mail: jrs1030@psu.edu.
}

(Dieringer, 1991; Ollerton and Lack, 1998).

Norway maple is one species that has been identified as potentially invasive to natural areas (Munger, 2003; Randall and Marinelli, 1996; Swearingen et al., 2002; Webb and Kaunzinger, 1993; Webb et al., 2001; Wyckoff and Webb, 1996). Based on observations, the norway maple produces high quantities of seed, shadetolerant seedlings, and dense canopies that further reduce light and moisture reaching the understory (Gresham, 2000; Randall, 1996). Ecological researchers have reported that these affects on a forest community alter its structure by decreasing native species abundance, diversity (Munger, 2003), and richness (Martin, 1999; Webb et al., 2001; Wyckoff and Webb, 1996).

It is logical to assume that less invasive or noninvasive cultivars of the invasive species may exist among the present or previously popular cultivars employed in the green industry (Lehrer and Brand, 2003). Few studies have addressed flower and seed yields along with other biologic traits in determining the invasive potential of cultivars for known invasive species. Of the studies reported, all have focused on shrub (Anisko and Im, 2001; Knox and Wilson, 2006; Lehrer et al., 2006; Lovinger and Anisko, 2004; Wilson et al., 2004a, 2004 b), perennial grasses (Meyer and Tchida, 1999), or herbaceous species (Wilson and Mecca, 2003). The immediate value of cultivar evaluation for seed production is the ability to advise the green industry of problem cultivars and possible replacements (Wheeler and Starrett, 2001). The replacements may include reintroducing older, less prolific cultivars that have been replaced by new cultivars. With any cultivar evaluation, the process begins with defining flower and seed productivity.

The purpose of this study was to determine the flower and seed productivity of the norway maple and its cultivars. This is the first report in which norway maple cultivars have been evaluated using seed productivity to determine each cultivar's invasive potential.

\section{Materials and methods}

Plant and site selection. The Holden (Kirtland, $\mathrm{OH}$; lat. $41^{\circ} 36^{\prime} \mathrm{N}$, long. $81^{\circ} 18^{\prime} \mathrm{W}$; USDA Hardiness Zone 5) and Dawes (Newark, OH; lat. $39^{\circ} 58^{\prime} \mathrm{N}$, long. $82^{\circ} 24^{\prime} \mathrm{W}$; USDA Hardiness Zone 6) Arboretums were chosen for this research because of the presence of selected cultivars, the availability of replication, and specimens of similar age. 'Emerald Queen', 'Rubrum', and the species were researched at the Holden Arboretum. 'Columnare', 'Crimson King', 'Faasen's Black', 'Globosum', and the species were observed at the Dawes Arboretum. Cultivars were assessed annually for 3 years (2004-06) to define their flower and seed production.

FLOWER AND SEED PRODUCTION CHARACTERIZATION. To characterize flower and seed production of the test plants (two to three plants/cultivar), several different data collection techniques were used. Initially, four entire lateral branches off of the main stem of each cultivar were randomly

\begin{tabular}{llll}
\hline $\begin{array}{l}\text { Units } \\
\begin{array}{l}\text { To convert U.S. to SI, } \\
\text { multiply by }\end{array}\end{array}$ & U.S. unit & SI unit & $\begin{array}{l}\text { To convert SI to U.S., } \\
\text { multiply by }\end{array}$ \\
\hline 0.3048 & $\mathrm{ft}$ & $\mathrm{m}$ & 3.2808 \\
2.54 & inch $(\mathrm{es})$ & $\mathrm{cm}$ & 0.3937
\end{tabular}


selected for use over the study period and were marked at various heights of the canopy and from each cardinal direction to obtain a consistent estimate of flower and seed production throughout the tree. High branches that could not be reached on the ground were accessed using climbing equipment or ladders, and low branches were accessed from the ground by hand. Branches that were difficult to reach were pulled down and accessed using pole pruners.

Each year, in late April, 10 flower clusters/branch were randomly selected and the number of flowers / cluster were recorded and used to calculate the average number of flowers/ cluster. Total flower clusters were also counted for each marked branch. Annual flower production estimates were then calculated for each branch (total flower clusters $\times$ average number of flowers/cluster). The diameter of each marked branch and all primary branches were also recorded and used to calculate the cross-sectional area of each branch $\left[\mathrm{A}=(p i \div 4) \times \mathrm{d}^{2}\right.$, where $\mathrm{A}=$ cross-sectional area, $p i=3.14$, and $\mathrm{d}=$ branch diameter]. The percentage of canopy area covered by each marked branch was then calculated (marked branch cross-sectional area $\div$ sum of all primary branch cross-sectional areas).

From these calculations, annual total flower production was estimated for each cultivar (annual flower production estimates $\div$ percentage of canopy area covered) with the assumption that flower production was proportional to branch cross-sectional area. Plant height, lowest branch height aboveground, and canopy dimensions were also recorded for each cultivar. These data were used to calculate the surface area of each cultivar with the formula for one-half an ellipsoid: $a \geq b \geq c$ (Wolfram, 1996). This formula was chosen because it best represents the canopy shape of each norway maple cultivar. Surface areas were numerically calculated using Mathematica (version 4.1; Wolfram Research, Champaign, IL). Flower densities standardized per unit area were then estimated for each cultivar (annual total flower production estimates $\div$ surface area). Branch length and trunk diameter at breast height $(\mathrm{DBH}=$ diameter at 54 inches aboveground) data were also collected to monitor plant size for the cultivars over the study period. In late August or early September, cultivar seed densities were determined using previously marked branches with the same equipment and methods.

Flower and seed counting dates were chosen based on average bloom or seed dispersal dates along with visual observation of full bloom or seed maturity. Samaras were considered mature when fruit was the appropriate size and yellow to brown in color.

Statistical analysis. Descriptive statistics that included means and standard errors were determined for plant size measurements by averaging over the 3-year period to summarize plant size.

Annual flower and seed densities for each of the 3 years were subjected to one-way analysis of variance using the MIXED procedure of SAS (version 9.1; SAS Institute, Cary, NC) to determine if cultivars influenced these variables. The cultivar or species was considered to be a fixed effect and the tree and branches nested in the tree were random effects. Fisher's least significant difference was then used to make pairwise comparisons of the least squares means (Lsmeans) if cultivar effects were significant $(P \leq 0.05)$. Annual flower and seed densities were to assure homogeneity of variance for the norway maple cultivars. A square root transformation of flower densities was also used in 2006 to assure homogeneity of variance because logarithmic transformations resulted in heteroscedasticity. These transformations were used when making pairwise comparisons; however, reported Lsmeans were from untransformed data. Statistics were performed using SAS (version 9.1) and graphs were generated with SigmaPlot (version 9.0; Systat Software, San Jose, CA).

\section{Results}

Plant size measurements. Differences in plant height, canopy dimensions, DBH, branch diameter, and branch length were noted, and on the whole, plants were healthy with positive yearly growth. All cultivars were 40 to 52 years old (Table 1 ).

FlOWER PRODUCTION. Flower production varied among the cultivars and species over the study period (2004-06). 'Emerald Queen' produced prolific to moderate flower yields for 2 years, 'Rubrum' showed high yields for 1 year, and 'Columnare' and the species showed moderate production for 1 year. 'Crimson King', 'Globosum', and 'Faasen's Black' were among the lowest in producing flower yields over the study (Fig. 1).

From year to year, flower production increased for most cultivars. 'Emerald Queen' was the exception and showed a decrease of 2399 flowers from 2004 to 2005. 'Rubrum' (694) showed the highest change in flower production. From 2005 to 2006, 'Emerald Queen' (1575), 'Columnare' (1160), 'Rubrum' (1141), and the species (722) showed the highest change in flower production. 'Globosum' (281) and 'Crim-

$$
\mathrm{SA}=0.5 \times \int_{0}^{2 p i} \int_{0}^{p i} \sin t \sqrt{\mathrm{b}^{2} \times \mathrm{c}^{2} \times \sin ^{2} t \times \cos ^{2} p+\mathrm{a}^{2} \times \mathrm{c}^{2} \times \sin ^{2} t \times \sin ^{2} p+\mathrm{a}^{2} \times \mathrm{b}^{2} \times \cos ^{2} t} d t d p
$$

where $\mathrm{SA}=$ surface area; $p i=3.14 ; t=$ theta and $p=$ phi were angles of integration; and $\mathrm{a}, \mathrm{b}$, and $\mathrm{c}$ were canopy height (plant height - lowest branch height), $0.5 \times$ canopy length, and $0.5 \times$ canopy width such that analyzed individually over the 3 years and were not combined to reflect variation in productivity or lack thereof for the norway maple cultivars.

In 2005, flower and seed densities were logarithmically transformed son King' (229) showed the fewest changes (Fig. 1).

Seed Production. Seed yields were significantly different among cultivars each year of the study (2004-06). 'Columnare', 'Emerald 
Table 1. Plant size measurements for norway maple cultivars and species at the Dawes (Newark, OH) and Holden (Kirtland, $\mathrm{OH})$ Arboretums averaged over a period of 3 years. Values are means \pm standard errors.

\begin{tabular}{|c|c|c|c|c|c|c|c|c|}
\hline Cultivar & $\begin{array}{l}\text { Samples } \\
\text { (no.) }\end{array}$ & $\begin{array}{l}\text { Planting } \\
\text { date }(y \mathbf{y})\end{array}$ & $\begin{array}{c}\text { Plant } \\
\text { ht }(\mathrm{m})^{\mathrm{z}}\end{array}$ & $\begin{array}{c}\text { Canopy } \\
\text { dimensions (m) }\end{array}$ & $\begin{array}{c}\text { Lowest } \\
\text { branch }^{\mathrm{y}}(\mathrm{m})\end{array}$ & $\mathrm{DBH}(\mathrm{cm})^{\mathrm{x}}$ & $\begin{array}{c}\text { Branch } \\
\text { diam } \\
(\mathrm{cm})\end{array}$ & $\begin{array}{c}\text { Branch } \\
\text { length } \\
(\mathrm{m})\end{array}$ \\
\hline Columnare & 3 & 1957 & $9.5 \pm 0.4$ & $9.6 \pm 0.5 \times 8.9 \pm 0.3$ & $1.2 \pm 0.1$ & $51.4 \pm 3.5$ & $4.5 \pm 0.1$ & $7.9 \pm 0.4$ \\
\hline Emerald Queen & 2 & 1964 & $12.9 \pm 0.3$ & $13.8 \pm 0.5 \times 11.9 \pm 0.5$ & $1.4 \pm 0$ & $52.7 \pm 0.7$ & $6.1 \pm 0.1$ & $8.0 \pm 0.3$ \\
\hline Faasen's Black & 2 & 1958 & $6.5 \pm 0$ & $7.6 \pm 0.3 \times 7.4 \pm 0.4$ & $0.9 \pm 0.1$ & $28.7 \pm 2.1$ & $3.8 \pm 0.1$ & $8.8 \pm 0.4$ \\
\hline Globosum & 2 & 1957 & $4.7 \pm 0$ & $6.8 \pm 0.4 \times 6.8 \pm 0.3$ & $1.7 \pm 0$ & $28.7 \pm 1.6$ & $3.0 \pm 0.1$ & $5.1 \pm 0.3$ \\
\hline Species & 2 & $\begin{array}{c}1962 \\
\text { and } 1955\end{array}$ & $11.9 \pm 1.4$ & $14.1 \pm 0.4 \times 13.5 \pm 0.3$ & $1.1 \pm 0.2$ & $72.1 \pm 4.8$ & $5.9 \pm 0.1$ & $9.6 \pm 0.5$ \\
\hline
\end{tabular}

${ }^{\mathrm{z}} 1 \mathrm{~m}=3.2808 \mathrm{ft}$.

Lowest branch height aboveground.

${ }^{\mathrm{x}} \mathrm{DBH}=$ Diameter at breast height $[54$ inches aboveground $(137.2 \mathrm{~cm})], 1 \mathrm{~cm}=0.3937$ inch.

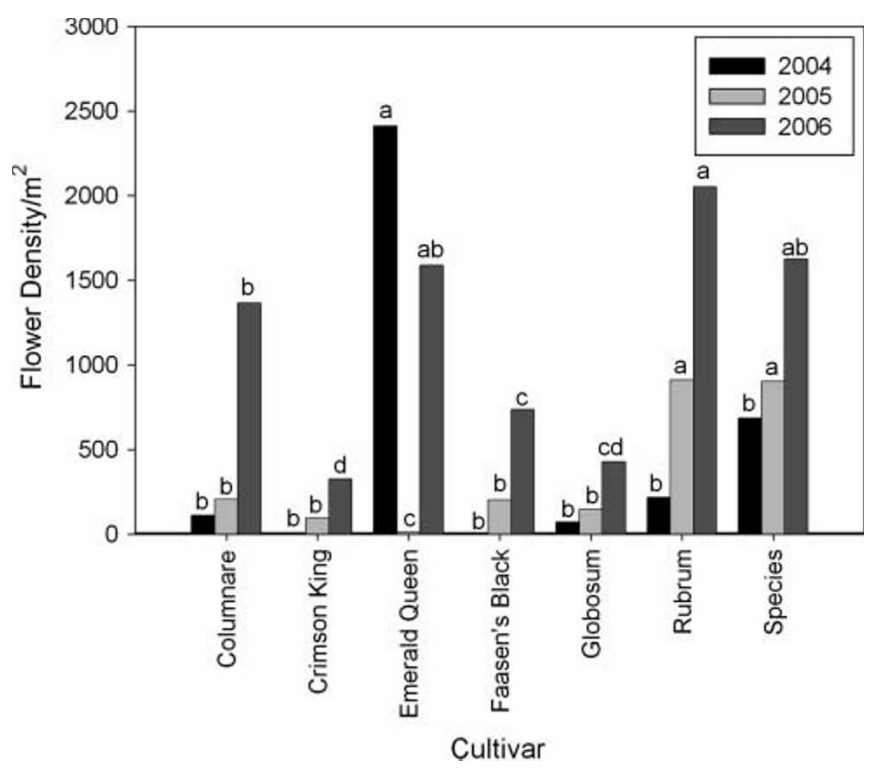

Fig. 1. Flower densities standardized per unit area on norway maple cultivars or species located at the Dawes (Newark, $\mathrm{OH}$ ) and Holden (Kirtland, $\mathrm{OH}$ ) Arboretums during Apr. 2004, 2005, and 2006. All values are least squares means. Mean separation of cultivars within the same year (lowercase letters) by Fisher's least significant difference test at $P \leq 0.05\left(1 \mathrm{~m}^{2}=10.7639 \mathrm{ft}^{2}\right)$.

Queen', and the species produced many seeds for 1 year. 'Crimson King', 'Faasen's Black', 'Globosum', and 'Rubrum' consistently formed few to no seeds (Fig. 2).

Seed production increased for most cultivars from year to year. The species consistently showed the highest increase in seed yield (333 and 875 , respectively) over the study. Additionally, 'Columnare' (823) showed a high increase in seed yield from 2005 to 2006. 'Faasen's Black' (73), 'Globosum' (47), and 'Crimson King' (30) showed the fewest changes. 'Emerald Queen' (961) and 'Rubrum' (47) were the only cultivars that showed a drop in seed productivity over the study (Fig. 2).

\section{Discussion}

In conducting this study, we were unable to find equal-aged trees of all cultivars at any site investigated. The sites did provide replicates of cultivars of similar age for the tested cultivars; however, size differed across cultivars. All cultivars were well within the mature age for flowering and seeding because trees in temperate regions begin flowering between the ages of 10 and 15 and produce noteworthy yields within 25 to 30 years (Bonner, 2003).
An obvious constraint in evaluating landscape trees and related cultivars of a species for flower and seed production is the availability of replicated accessions. As this study represents the first attempt to address the invasiveness of norway maple cultivars, the cultivars and numbers of cultivars we chose were the most practicable for beginning the investigation of this issue. These cultivars do not represent the full compliment of cultivars in the market place. Finding equal-aged replicate samples of similar quality was also difficult. These cultivars have allowed us to test our approach to better define the range of flower and seed production in one landscape tree that has been strongly alleged to be invasive.

Of the norway maple cultivars observed, 'Columnare', 'Crimson King', 'Emerald Queen', 'Globosum', and the species are readily available in the trade, while 'Faasen's Black' and 'Rubrum' are not. Cultivars that are not readily available may have an economic resurgence in value and should be worthy of reconsideration by the industry if they produce few seeds because low-seed-producing cultivars are preferable in the landscape (Meyer and Tchida, 1999).

Observations on site confirmed that most trees were not flowering internally, but rather on the exterior ends of branches. The exception was where interior branches were open and received light. Because most cultivars were located at sunny sites and appeared to have an abundance of flowers on the outer branch tips, flower and seed production appeared unaffected by a lack of light intensity for these plants. 'Columnare', 


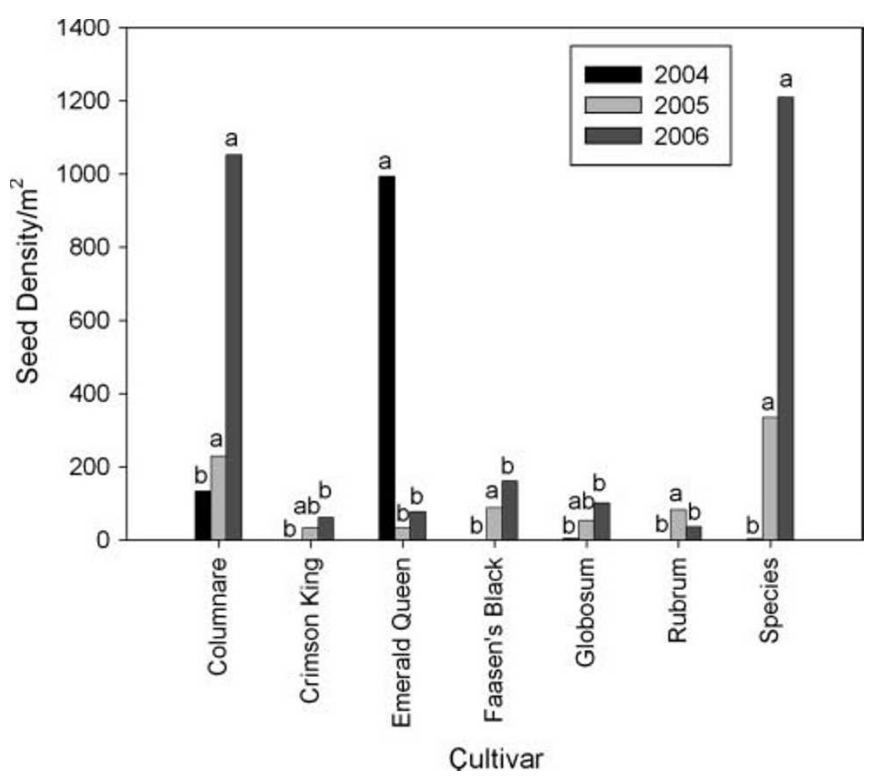

Fig. 2. Seed densities standardized per unit area on norway maple cultivars or species located at the Dawes (Newark, $\mathrm{OH}$ ) and Holden (Kirtland, $\mathrm{OH}$ ) Arboretums during Aug. and Sept. 2004, Sept. 2005, and Sept. 2006. All values are least squares means. Mean separation of cultivars within the same year (lowercase letters) by Fisher's least significant difference test at $P \leq 0.05\left(1 \mathrm{~m}^{2}=10.7639 \mathrm{ft}^{2}\right)$.

'Crimson King', and 'Emerald Queen' included branches that were subjected to partial shade conditions because of shade cast by competing trees nearby, which may have reduced flower and seed production on these branches; however, without a second series of replicate trees, this observation cannot be verified.

The affect of plant size on flower and seed yields is species dependent. Some plants display increased flower and seed with increased plant size. Other plants do not follow this pattern (Garwood and Horvitz, 1985). This research represents the first attempt at quantifying and defining flower production and seed differences among norway maple cultivars.

Because of the insurmountable time and labor required to collect total flower and seed densities relative to the surface canopy area, marked branches were used to estimate total flower and seed densities on norway maple cultivars. Flower and seed densities differed each year (2004-06) for the cultivars. 'Crimson King', 'Globosum', and 'Faasen's Black' were among the lowest producing in flower and seed yields over the 3-year study period. 'Rubrum' produced prolific flower yields for 1 year and yielded few seeds throughout the study. 'Columnare', 'Emerald Queen', and the species produced many flowers and seeds for 1 year. These observations on cultivar differences agree with similar studies on the butterfly bush (Buddleja), barberry (Berberis), miscanthus (Miscanthus), and mexican petunia (Ruellia) (Anisko and Im, 2001; Lehrer et al., 2006; Meyer and Tchida, 1999; Wilson and Mecca, 2003; Wilson et al., 2004b).

Variation in flower and seed densities was obvious from year to year for each cultivar. 'Columnare', 'Emerald Queen', and the species showed the most changes in flower and seed production. 'Crimson King' and 'Globosum' consistently displayed the fewest changes in flower and seed yields. Such observations on plant differences from one year to the next agree with similar studies on the fragrant snowbell (Styrax obassia) (Kato and Hiura, 1999). Variations such as these may occur from one year to the next to produce high yields because of endogenous cycles, weather conditions (Selas et al., 2002), or nutrient availability (Stephenson, 1981). Such variation from year to year further describe the erratic yields for 'Columnare', 'Emerald Queen', and the species and show that 'Crimson King' and 'Globosum' do not produce such differences.

When choosing among landscape plants of similar quality, it is desirable to select those with low seed production (Anisko and Im, 2001; Lovinger and Anisko, 2004; Meyer and Tchida, 1999). Because 'Columnare', 'Emerald Queen', and the species produced many seeds, they may be problematic in landscapes that adjoin natural areas and are good candidates for future exhaustive studies. 'Crimson King', 'Globosum', 'Faasen's Black', and 'Rubrum' consistently produced the fewest seeds for this study and may be suitable for continued use or reintroduction into the landscape where the invasive threat to surrounding communities are a concern.

To further this research effort, the relationship between and comparisons of flower and seed yields for cultivars could be determined, but this would require the use of uniform complete stands of trees. Additionally, to provide a clearer picture of each cultivar's invasive potential, future research on cultivar germination rates under a wide range of conditions, competitive abilities, seed and pollen viability, level of seed predation, and distance of seed dispersal could be conducted. Access to established, similar-aged, replicated stands of cultivars for trees such as the norway maple, which are under scrutiny for invasiveness, would be useful for in-depth seed productivity and dispersal research.

\section{Literature cited}

Anisko, T. and U. Im. 2001. Beware of butterfly bush. Amer. Nurse 194:46-49.

Augspurger, C.K. 1983. Phenology, flowering synchrony, and fruit set of six neotropical shrubs. Biotropica 15:257-267.

Bir, R.E. 2000. Invasive plants and the nursery industry. Combined Proc. Intl. Plant Prop. Soc. 50:490-492.

Bonner, F.T. 2003. Seed biology, p. 347. In: F.T. Bonner, R.T. Nisley. Woody plant seed manual. 13 July 2006. <http://www.nsl.fs.fed.us/wpsm/ Chapterl.pdf $>$.

D'Antonio, C.M. and P.M. Vitousek. 1992. Biological invasions by exotic grasses, the grass/fire cycle, and global change. Annu. Rev. Ecol. Syst. 23:63-87.

Dieringer, G. 1991. Variation in individual flowering time and reproductive success of Agalinis strictifolia (Scrophulariaceae). Amer. J. Bot. 78:497-503. 
Garwood, N.C. and C.C. Horvitz. 1985. Factors limiting fruit and seed production of a temperate shrub, Stachylea trifolia L. (Staphyleaceae). Amer. J. Bot. 72:453-466.

Gresham, C. 2000. Invasive plants in Pennsylvania. Dept. Conservation Natural Resources, Harrisburg, PA.

Kato, E. and T. Hiura. 1999. Fruit set in Styrax obassia (Styracaceae): The effect of light availability, display size, and local floral density. Amer. J. Bot. 86:495-501.

Knox, G.W. and S.B. Wilson. 2006. Evaluating north and south Florida landscape performance and fruiting of ten cultivars and a wild-type selection of Nandina domestica, a potentially invasive shrub. J. Environ. Hort. 24:137-142.

Lehrer, J.M. and M.H. Brand. 2003. Seed production levels and seedling traits of Berberis thunbergii cultivars. Combined Proc. Intl. Plant Prop. Soc. 53:472476.

Lehrer, J.M., M.H. Brand, and J.D. Lubell. 2006. Four cultivars of japanese barberry demonstrate differential reproductive potential under landscape conditions. HortScience 41:762-767.

Lovinger, S. and T. Anisko. 2004. Benign Berberis. Amer. Nurse 200:36-39.

Martin, P.H. 1999. Norway maple (Acer platanoides) invasion of a natural forest stand: Understory consequence and regeneration pattern. Biol. Invasions 1:215222.

Meyer, M. and C.L. Tchida. 1999. Miscanthus Anderss. produces viable seed in four USDA hardiness zones. J. Environ. Hort. 17:137-140.

Morin, N. 1999. Solving the invasive plant problem. Public Garden 14:1617.
Munger, G.T. 2003. Acer platanoides. 1 June 2007. <http://www.fs.fed.us/data base/feis/>.

Ollerton, J. and A. Lack. 1998. Relationships between flowering phenology, plant size and reproductive success in Lotus corniculatus (Fabaceae). Plant Ecol. 139:35-47.

Pimentel, D., L. Lach, R. Zungia, and D. Morrison. 1999. Environmental and economic costs associated with nonindigenous species in the United States. 15 Nov. 2004. <http://www.news.cor nell.edu/releases/Jan99/species_costs. html>.

Randall, J.M. 1996. Plant invaders: How non-native species invade and degrade natural areas, p. 7-12. In: J.M. Randall and J. Marinelli (eds.). Invasive plants weeds of the global garden. Brooklyn Bot. Garden, Brooklyn, NY.

Randall, J.M. and J. Marinelli. 1996. Invasive plants weeds of the global garden. Brooklyn Bot. Garden, Brooklyn, NY.

Selas, V., G. Piovesan, J.M. Adams, and M. Bernabei. 2002. Climatic factors controlling reproduction and growth of norway spruce in southern Norway. Can. J. For. Res. 32:217-225.

Stephenson, A.G. 1981. Flower and fruit abortion: Proximate causes and ultimate functions. Annu. Rev. Ecol. Syst. 12:253279.

Swearingen, J., K. Reshetiloff, B. Slattery, and S. Zwicker. 2002. Plant invaders of mid-Atlantic natural areas, guidebook. Natl. Park Serv. U.S. Fish Wildlife Serv., Washington, DC.

U.S. Department of the Interior. 1999. Invasive species fact sheet. White House, Office Press Secretary, Washington, DC.

Webb, S.L. and C.K. Kaunzinger. 1993. Biological invasion of the Drew University
(New Jersey) forest preserve by norway maple (Acer platanoides L.). Bull. Torrey Bot. Club 120:343-349.

Webb, S.L., T.H. Pendergast,IV and M.E. Dwyer. 2001. Response of native and exotic maple seedling banks to removal of the exotic, invasive norway maple (Acer platanoides). J. Torrey Bot. Soc. 128: 141-149.

Wheeler, A.R. and M.C. Starrett. 2001. Determining the invasive potential of Rhamnus frangula 'Asplenifolia' and 'Columnaris' based on seed germination. Combined Proc. Intl. Plant Prop. Soc. 51:397-400.

Wilcove, D.S., D. Rothstein, J. Dubow, A. Phillips, and E. Losos. 1998. Quantifying threats to imperiled species in the United States. Bioscience 48:607-615.

Wilson, S.B. and L.K. Mecca. 2003. Seed production and germination of eight cultivars and the wild type of Ruellia tweediana: A potentially invasive ornamental. J. Environ. Hort. 21:137-143.

Wilson, S.B., M. Thetford, L.K. Mecca, and J.S. Raymer. 2004a. Evaluation of 14 butterfly bush taxa grown in western and southern Florida: I. Visual quality, growth, and development. HortTechnology 14:605-611.

Wilson, S.B., M. Thetford, L.K. Mecca, J.S. Raymer, and J.A. Gersony. 2004b. Evaluation of 14 butterfly bush taxa grown in western and southern Florida: II. Seed production and germination. HortTechnology 14:612-618.

Wolfram, S. 1996. The mathematica book. 3rd ed. Wolfram Media, Cambridge Univ. Press, Champaign, IL.

Wyckoff, P.H. and S.L. Webb. 1996. Understory influence of the invasive norway maple (Acer platanoides). Bull. Torrey Bot. Club 123:197-205. 